\title{
Developing Co-creation-driven Innovation: the role of Customer Experience Orientation and Organizational Agility
}

\author{
Leonardus W Wasono Mihardjo, Sasmoko, Elidjen, Riza A.N. Rukmana
}

\begin{abstract}
This paper explores the concept of the 'co-creation-driven innovation' as part of the service dominant (S-D) logic concept in the digital ICT industry. The platform service becomes critical in order to collaborate and innovate based on organizational agility and customer experience. Co-creation-driven innovation is considered as part of the service dominant development, where a dynamic organization model and customer experience feedback are required in the shaping of business model innovations within the digital ecosystem. The study was performed with a sample size of 175 respondents representing Indonesian telecommunication firms. Smart PLS was used as the statistical tool for analyses. Findings demonstrate that customer experience orientation and organizational agility has a direct impact on digital co-creation and business model innovation. Simultaneous testing of hypotheses shows that customer experience orientation has an indirect influence on business model innovation through co-creation strategy. However, organizational agility does not have any indirect impacts. The study has some limitations in terms of the time period and sample size, therefore suggestions for future studies are included in the paper
\end{abstract}

Index Terms: customer experience orientation, organizational agility, digital co-creation, business model innovation, service dominant logic

\section{INTRODUCTION}

Industry 4.0, through digital technology such as the Internet, mobile, cloud computing, and big data has enabled firms to perform in new paradigms in terms of design, interactions, and collaborations of products and services. This is considered to be vital in order to co-create new values in the digital environment, especially to maximize the use of the platforms. These platforms have enabled the development of information systems as part of the development of the service ecosystem and competitive advantage (Ercsey, 2017). The concept of collaboration in service creation that focuses more on the processes and mechanisms related to interaction activities, which is valuable to the generation that seeks for two-way interactions related to customer and organizational learning (Frow,

\footnotetext{
Revised Manuscript Received on September 22, 2019.

Leonardus W Wasono Mihardjo, School of Business, Bina Nusantara University, Jakarta, Indonesia.

Sasmoko, Primary Teacher Education Departmeny, Bina Nusantara University, Jakarta, Indonesia. Email: sasmoko@binus.edu

Elidjen , School of Business, Bina Nusantara University, Jakarta, Indonesia.

Riza A.N. Rukmana, Industrial Engineering Department, Telkom University, Bandung, Indonesia.
}

Nenonen, Payne, and Storbacka, 2015). Collaborations through service platforms also induce innovation in the business model, thus co-creating new valuable ideas and practices in combining the resources for knowledge and capability (Romero and Molina, 2011).

The concept of co-creation driven innovation is derived from the combination of business model innovation and co-creation based on the SD logic. Based on this logic, performance is shaped based on the exchange of tangible goods between multiple actors with intangible services to grow mutually in co-creation (Vargo and Lusch, 2004). The SD logic concept focuses on the customers or partners, which is where firms should introduce the service ecosystem while concurrently upgrading their capabilities in the service platform, including their potential future performances in relation to customer needs (Vargo and Lusch, 2016).

The customer paradigm have shifted objectives, from solely customer satisfaction to maximizing a more positive customer experience (Brochado, Troilo, and Shah, 2017; Meyer and Schwager, 2007; Palmer, 2010). The combination of co-creation and customer involvement covers all the ranges of collaboration, starting from the ideas, co-designs, and co-promotion have led to improved customer experiences (Romero and Molina, 2011). From a company's perspective, organization agility is required to distinguish parts of the organization based on its strategy (Roser, T., DedFillippi, R., Samson, 2013). Organizational agility is a part of the dynamic capabilities to recognize opportunities, seize design opportunities, and transform capabilities in the development of business model innovation (Teece, Peteratd, and Leih, 2016). Based on observations in a dynamic environment, firms should enable the capabilities in order to create a collaborative innovation based on the customer journey (Chesbrough, 2010).

This paper focuses on the concept of co-creation driven innovation, which has become a part of organisational agility. The concept is based on customers' needs to be able to act fast along with the market dynamics and turbulences associated to globalization (Camarinha-Matos, 2007). Past studies have discussed the fundamental concept of collaboration and co-creation in relation to organization agility (Roser, DedFillippi, and Samson, 2013) and the co-creation of business models (Basceanu, 2014). However, the use of co-creation and business models in this dynamic environment, especially in relation to customer experience orientation and organizational agility has not been explored further. This is evident in empirical studies as co-creation

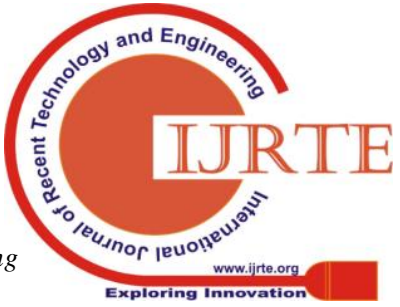


driven innovation integrates customer experience orientation and organizational agility in order to provide fast reactions and better adaptation to the market dynamics.

Hence, this study aims to result in a framework that relies on co-creation driven innovation within the context of the SD logic with a background of customer experience and organizational agility. This paper starts with a literature review, followed by the research model, hypotheses, methodology, research findings, as well as a discussion that includes implications of the findings. The paper concludes with a summary of the study, mentioning the limitations and suggestions for future research.

\section{LITERATURE REVIEW}

The SD logic explains the value of co-creation between organization capabilities and customers in the context of collaboration (Vargo and Lusch, 2004). SD logic focuses on services as the platform and ecosystem that is beneficial to the respective actors and enables the fundamental components of service exchange (Vargo and Lusch, 2016). It focuses on customers' needs to give space for the agility of the organization to focus on the process in creating value based on a customer-centric approach (Romero and Molina, 2011; Xie, Wu, Xiao, and Hu, 2016). Value creation is defined as the firm's values as part of the collaboration between customers and service providers. Whereas service providers could deliver the values of customer journey in creating customer experience (Shrivastava, 2016; Ramaswamy, 2008; Sjödin and Kristensson, 2012). In the digital era, technology has a significant influence in collaboration and it is designed based on customer experience and organization agility, also known as digital co-creation (Richter, Trier, and Richter, 2017; Xie et al., 2016) as shown in Figure 1.

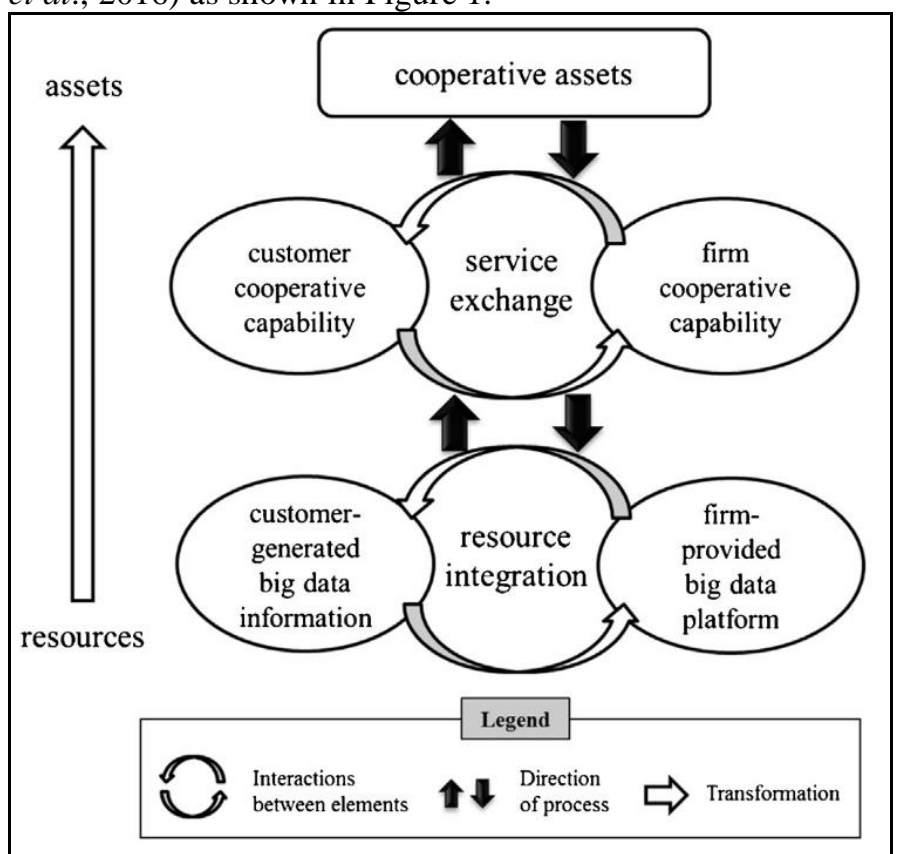

Figure 1. co-creation based on customer and firms (Xie et al., 2016)

Digital co-creation is derived from co-creation strategy that consists of co-creation vision, capability, and tactics (Mihardjo, Sasmoko, Alamsjah, and Elidjen, 2018), aiming to perform business model innovation. Past studies on business model innovation could be defined as business model canvasser as part of diagram block to guide the processing model in creating a business model (Osterwalder and Pigneur, 2010). Other studies define business model innovation as an integrated business model that consists of strategic components, customers, and value creation (Wirtz, Pistoia, Ullrich, and Göttel, 2016). Thus, the St. Gallen business model navigators consists includes four questions that needs to be answered when creating a business model: who, what, how, and value (Gassmann, Frankenberger, and Csik, 2014). Zott and Amit (2017) defined business model innovation in the digital era as part of content innovation, structure innovation, and governance innovation.

Co-creation that is based on innovation was constructed from integration between organizational agility and customer experience orientation. Organizational agility is defined as the operational capabilities to adapt to change as fast as the market or customer requirements in order to provide flexibility in adjusting its internal structures and processes (Trinh-Phuong, Molla, and Peszynski, 2010). To adapt to the changes, organizational agility becomes a fundamental asset for firms that consist of people, process, and culture agility (Crocitto and Youssef, 2003; Nold and Michel, 2013). Meanwhile, customer experience orientation is defined as the firm's orientation to focus on the development of the firm's capability based on the customer journey in order to provide customer experience (Lemon and Verhoef, 2016). Hence, it focuses more on the development of products and services to align with customer expectations starting from customer relations, product trust and personalization, price offer, and brand performance. It is also related to the service to capture the behaviour, cognition, and emotions of the customers (Ramaswamy, 2011).

According to past studies, the ability of organizations to adapt to change by developing people who are agile, process and culture has a significant impact on the development of business model innovation (Loss and Crave, 2011). The agile business model brings a new appeal to companies in the digital era to speed up decision making processes in a dynamic environment (Teece et al., 2016) in many areas, including small and medium enterprise (Arbussa, Bikfalvi, \& Marquès, 2017). This enhances the process through an enterprise resources plan (ERP) (Seethamraju and Krishna Sundar, 2013). Hence, the first hypothesis is formulated as the following:

\section{Hypothesis 1: Organizational Agility has a significant impact on Business Model Innovation} The development of co-creation can be supported by an integration of organization agility and customer experience to support the development of service dominant logic (Sharma, Conduit, and Hill, 2014). This enables the firm to have collaboration capability (Kodama, 2018; Romero and Molina, 2011). Hence, the second hypothesis is formulated as the following:
Hypothesis Organizational 
agility and customer experience orientation have significant impact on digital co creation

Firms that focus on customer experience could leverage its innovation in business model (Seppanen and Laukkanen, 2015) and co-creation and is strongly correlated to business model innovation (Basceanu, 2014; Mihardjo, Alamsjah, Elidjen, and Sasmoko, 2018). Hence, leading to the formulation of the last two hypotheses:

Hypothesis 3: Customer Experience Orientation has a significant impact on Business Model innovation

Hypothesis 4: Digital co-creation has a significant impact on Business Model innovation The research model for the current study is demonstrated in figure 2 .

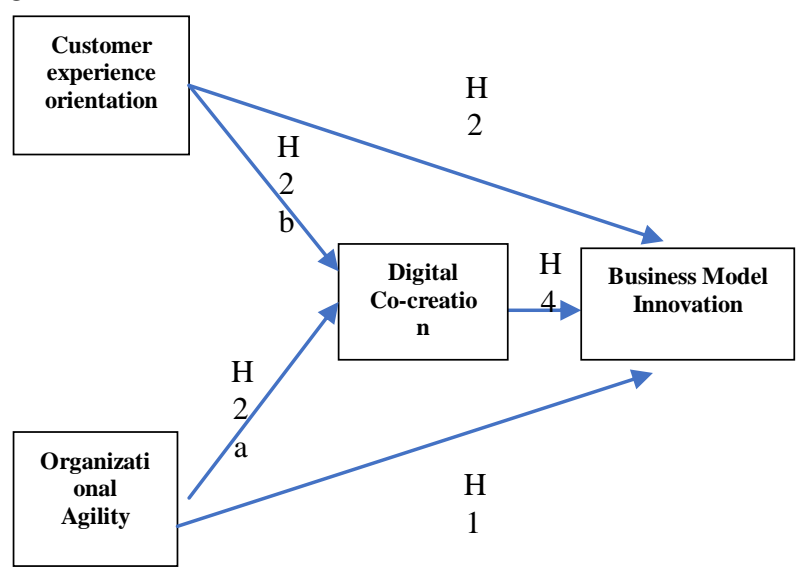

Figure 2. Research model

\section{METHOD}

\section{Research design:}

The current study investigates the service-dominant logic concept, through an assessment on co-creation driven innovation by integrating customer experience orientation and organizational agility.

\section{Population and sample:}

There are 542 ICT firms that are currently operating in Indonesia according to the Ministry of Information and Communication (2017), out of which the ones in this study consists of network providers, service providers and supporting ICT companies in tower companies. The five dimensions determine the appropriate sample size needed for this (Pallant, 2005). With 35 indicators, the sample is selected from 175 firms. Smart PLS was used to analyse and process the collected data.

\section{Sampling technique:}

Simple random sampling was used to allow respondents to have equal chances to be selected for data collection (Hair, Ringle, Sarstedt, and Vinzi, 2014) with the firms as the units of analyses. A seven-point Likert scale ranging from 1 ('Not at all satisfied') to 7 (very satisfied') was used to examine the response for each construct of the study.

\section{RESUlt}

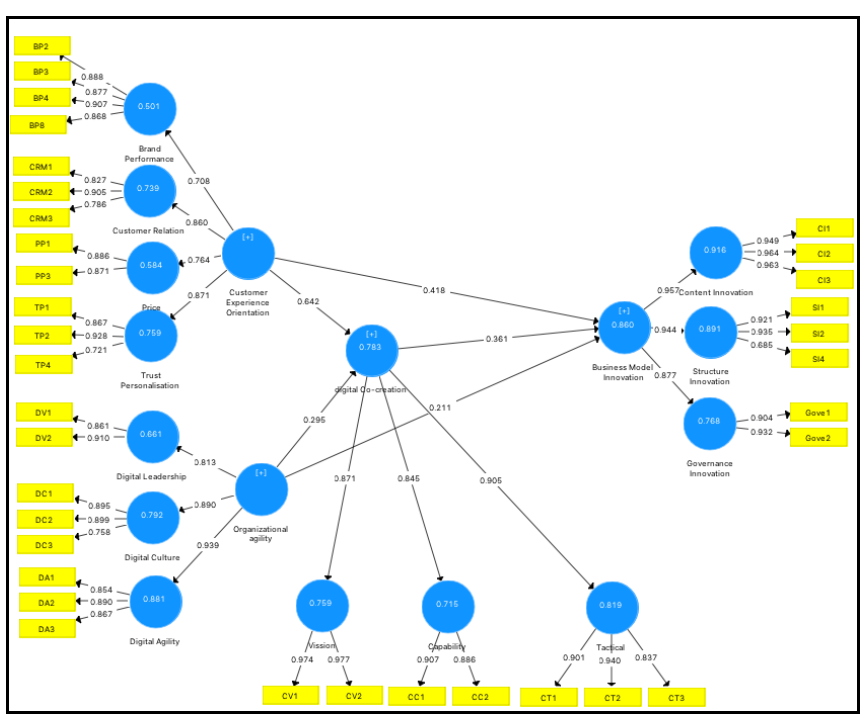

Figure 3. Measurement Test Result

Figure 3 demonstrates the result of measurement test to validate the reliability, consistency and validity of latent variable, dimensions, and indicators. Indicators and dimensions generally have loadings of Cronbach's Alpha (CA) and composite reliability (CR) above 0.7 . The average variance extracted (AVE) is used to evaluate convergent validity exceeding the 0.5 level. Results are shown in Table 1 , where the all latent variable was valid.

Table 1. Construct Reliability and Validity

\begin{tabular}{|l|c|c|c|c|c|}
\hline & Cronbach's Alpha & rho_A & Composite Reliability & AVE & Remarks \\
\hline Organizational agility & 0.904 & 0.910 & 0.922 & 0.571 & Valid \\
\hline $\begin{array}{l}\text { Customer Experience } \\
\text { Orientation }\end{array}$ & 0.935 & 0.942 & 0.943 & 0.529 & Valid \\
\hline Digital Co-creation & 0.908 & 0.916 & 0.927 & 0.647 & Valid \\
\hline $\begin{array}{l}\text { Business Model } \\
\text { Innovation }\end{array}$ & 0.942 & 0.951 & 0.953 & 0.720 & Valid \\
\hline
\end{tabular}

The next step was determining the discriminant validity. Table 2 demonstrates cross-loading test results where according to Fornell and Cha (1994), the values are higher than 0.6 , indicating that at least one dimension is unrelated to others. 
Table 2. Cross Loading Test Result

\begin{tabular}{|c|c|c|c|c|c|c|c|c|c|c|c|c|c|c|}
\hline & $\begin{array}{l}\text { Brand } \\
\text { Perf }\end{array}$ & Capability & $\begin{array}{c}\text { Content } \\
\text { Innov }\end{array}$ & $\begin{array}{c}\text { Cust. } \\
\text { Relation }\end{array}$ & $\begin{array}{l}\text { Digital } \\
\text { Agility }\end{array}$ & $\begin{array}{c}\text { Digital } \\
\text { Culture }\end{array}$ & $\begin{array}{l}\text { Digital } \\
\text { Leader }\end{array}$ & $\begin{array}{l}\text { Gov. } \\
\text { Innov }\end{array}$ & $\begin{array}{l}\text { Org. } \\
\text { agility }\end{array}$ & Price & $\begin{array}{l}\text { Structure } \\
\text { Innov }\end{array}$ & Tactical & $\begin{array}{c}\text { Trust } \\
\text { Personal }\end{array}$ & Vision \\
\hline BP3 & 0.877 & 0.100 & 0.170 & 0.393 & 0.329 & 0.459 & 0.112 & 0.429 & 0.310 & 0.529 & 0.269 & 0.365 & 0.390 & 0.392 \\
\hline BP4 & 0.907 & 0.269 & 0.293 & 0.615 & 0.586 & 0.600 & 0.313 & 0.646 & 0.548 & 0.386 & 0.442 & 0.337 & 0.437 & 0.547 \\
\hline BP8 & 0.868 & 0.227 & 0.315 & 0.501 & 0.430 & 0.512 & 0.192 & 0.532 & 0.405 & 0.411 & 0.396 & 0.340 & 0.447 & 0.491 \\
\hline $\mathrm{CC} 1$ & 0.200 & 0.907 & 0.739 & 0.632 & 0.517 & 0.408 & 0.488 & 0.595 & 0.671 & 0.435 & 0.703 & 0.599 & 0.691 & 0.636 \\
\hline $\mathrm{CC} 2$ & 0.178 & 0.886 & 0.627 & 0.482 & 0.327 & 0.328 & 0.506 & 0.423 & 0.487 & 0.477 & 0.496 & 0.599 & 0.483 & 0.477 \\
\hline CI1 & 0.090 & 0.701 & 0.949 & 0.613 & 0.499 & 0.416 & 0.517 & 0.607 & 0.634 & 0.557 & 0.750 & 0.647 & 0.695 & 0.615 \\
\hline $\mathrm{CI} 2$ & 0.312 & 0.733 & 0.964 & 0.689 & 0.542 & 0.460 & 0.477 & 0.778 & 0.687 & 0.603 & 0.856 & 0.721 & 0.810 & 0.706 \\
\hline CRM1 & 0.381 & 0.456 & 0.603 & 0.827 & 0.648 & 0.562 & 0.611 & 0.520 & 0.685 & 0.356 & 0.647 & 0.485 & 0.489 & 0.716 \\
\hline CRM2 & 0.256 & 0.684 & 0.681 & 0.905 & 0.579 & 0.467 & 0.605 & 0.446 & 0.690 & 0.348 & 0.735 & 0.478 & 0.676 & 0.672 \\
\hline CRM3 & 0.655 & 0.438 & 0.508 & 0.786 & 0.436 & 0.441 & 0.431 & 0.608 & 0.522 & 0.519 & 0.563 & 0.585 & 0.725 & 0.509 \\
\hline CT1 & 0.406 & 0.449 & 0.486 & 0.437 & 0.223 & 0.296 & 0.450 & 0.515 & 0.391 & 0.639 & 0.429 & 0.901 & 0.557 & 0.464 \\
\hline $\mathrm{CT} 2$ & 0.455 & 0.564 & 0.564 & 0.541 & 0.331 & 0.433 & 0.558 & 0.648 & 0.522 & 0.652 & 0.504 & 0.940 & 0.605 & 0.554 \\
\hline CT3 & 0.199 & 0.743 & 0.871 & 0.658 & 0.458 & 0.401 & 0.585 & 0.670 & 0.635 & 0.616 & 0.692 & 0.837 & 0.733 & 0.713 \\
\hline CV1 & 0.524 & 0.602 & 0.708 & 0.747 & 0.759 & 0.669 & 0.578 & 0.745 & 0.779 & 0.452 & 0.845 & 0.598 & 0.660 & 0.974 \\
\hline $\mathrm{CV} 2$ & 0.462 & 0.616 & 0.740 & 0.712 & 0.758 & 0.685 & 0.637 & 0.768 & 0.798 & 0.462 & 0.882 & 0.681 & 0.669 & 0.977 \\
\hline DA1 & 0.298 & 0.295 & 0.372 & 0.485 & 0.854 & 0.710 & 0.589 & 0.470 & 0.761 & 0.022 & 0.557 & 0.196 & 0.282 & 0.546 \\
\hline DA2 & 0.369 & 0.595 & 0.684 & 0.621 & 0.890 & 0.763 & 0.628 & 0.682 & 0.874 & 0.395 & 0.739 & 0.365 & 0.479 & 0.730 \\
\hline DC1 & 0.356 & 0.380 & 0.442 & 0.505 & 0.757 & 0.895 & 0.618 & 0.428 & 0.829 & 0.295 & 0.529 & 0.426 & 0.387 & 0.545 \\
\hline DC2 & 0.480 & 0.198 & 0.229 & 0.395 & 0.705 & 0.899 & 0.381 & 0.336 & 0.704 & 0.177 & 0.397 & 0.180 & 0.256 & 0.449 \\
\hline DC3 & 0.582 & 0.466 & 0.575 & 0.580 & 0.759 & 0.798 & 0.515 & 0.739 & 0.730 & 0.477 & 0.674 & 0.471 & 0.513 & 0.781 \\
\hline DV1 & 0.237 & 0.455 & 0.440 & 0.483 & 0.466 & 0.467 & 0.861 & 0.453 & 0.643 & 0.262 & 0.433 & 0.586 & 0.369 & 0.424 \\
\hline DV2 & 0.129 & 0.521 & 0.519 & 0.652 & 0.717 & 0.586 & 0.910 & 0.497 & 0.787 & 0.140 & 0.637 & 0.492 & 0.346 & 0.660 \\
\hline Gove1 & 0.703 & 0.394 & 0.580 & 0.532 & 0.605 & 0.562 & 0.356 & 0.904 & 0.583 & 0.596 & 0.652 & 0.543 & 0.577 & 0.709 \\
\hline Gove2 & 0.401 & 0.638 & 0.796 & 0.621 & 0.630 & 0.520 & 0.611 & 0.932 & 0.723 & 0.458 & 0.732 & 0.714 & 0.616 & 0.717 \\
\hline PP1 & 0.385 & 0.489 & 0.619 & 0.465 & 0.316 & 0.393 & 0.319 & 0.503 & 0.435 & 0.886 & 0.446 & 0.690 & 0.594 & 0.476 \\
\hline PP3 & 0.539 & 0.400 & 0.469 & 0.401 & 0.251 & 0.257 & 0.059 & 0.493 & 0.273 & 0.871 & 0.302 & 0.559 & 0.580 & 0.343 \\
\hline SI1 & 0.350 & 0.639 & 0.779 & 0.725 & 0.759 & 0.582 & 0.699 & 0.777 & 0.798 & 0.373 & 0.921 & 0.605 & 0.646 & 0.901 \\
\hline SI2 & 0.296 & 0.689 & 0.834 & 0.731 & 0.627 & 0.505 & 0.505 & 0.695 & 0.696 & 0.353 & 0.935 & 0.529 & 0.693 & 0.836 \\
\hline SI4 & 0.313 & 0.348 & 0.560 & 0.487 & 0.501 & 0.544 & 0.326 & 0.418 & 0.583 & 0.392 & 0.685 & 0.442 & 0.509 & 0.469 \\
\hline TP1 & 0.352 & 0.589 & 0.763 & 0.721 & 0.432 & 0.368 & 0.385 & 0.589 & 0.541 & 0.641 & 0.620 & 0.603 & 0.867 & 0.629 \\
\hline TP2 & 0.309 & 0.733 & 0.792 & 0.723 & 0.435 & 0.427 & 0.369 & 0.543 & 0.581 & 0.576 & 0.709 & 0.671 & 0.928 & 0.612 \\
\hline TP4 & 0.537 & 0.294 & 0.404 & 0.441 & 0.347 & 0.356 & 0.243 & 0.515 & 0.390 & 0.458 & 0.490 & 0.532 & 0.721 & 0.466 \\
\hline
\end{tabular}

H2a: Investigations on the relationship between organizational agility and digital co-creation demonstrates

The structural test is used to determine the loading factor of the direct and indirect hypotheses. The direct hypothesis testing aims to assess the direct, significant relations between two latent variables.

H1: The first hypothesis examines the relationship between organizational agility and business model innovation. Tests show that $\mathrm{t}$-value was observed as 2.352 and $\mathrm{p}<0.05$, indicating that $\mathrm{H} 1$ is accepted. the t-values and p-values as 2.038 and $p<0.005$, therefore, $\mathrm{H} 2 \mathrm{a}$ is accepted.

H2b: Investigations on the relationship between customer experience orientation and digital co-creation shows that the $\mathrm{t}$-value as 4.279 and $\mathrm{p}>0.005$; therefore, H2b is accepted.

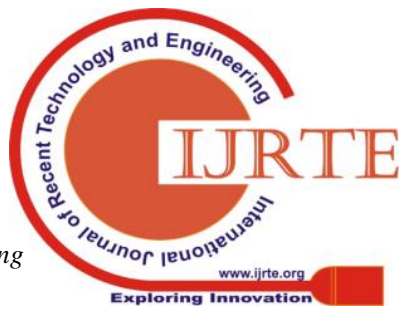


H3: The relationship between 'customer experience orientation and business model innovation', shows results indicating the $\mathrm{t}$-value as 2.084 and $\mathrm{p}>0.005$; therefore, $\mathrm{H} 3$ is accepted.

H4: H4 investigates the relationship between 'digital co-creation and business model innovation', with results indicating the t-value as 2.213 and $\mathrm{p}>0.005$; therefore, $\mathrm{H} 4$ is accepted

Table 3 below demonstrates the direct relationships within the study.

Table 3. Direct hypothesis testing Result

\begin{tabular}{|l|l|r|r|r|r|}
\hline & \multicolumn{1}{|c|}{ Hypothesis } & \multicolumn{1}{|c|}{$\begin{array}{c}\text { Standard } \\
\text { Deviation }\end{array}$} & $\begin{array}{c}\text { Statistic } \\
\text { S }\end{array}$ & $\begin{array}{c}\text { Palue } \\
\text { s }\end{array}$ & Remarks \\
\hline H1 & Organizational agility -> Business Model Innovation & 0.100 & 2.352 & 0.019 & Significant \\
\hline H2a & Organizational agility -> digital Co-creation & 0.166 & 2.038 & 0.042 & Significant \\
\hline H2b & Customer Experience Orientation -> digital Co-creation & 0.146 & 4.279 & 0.000 & Significant \\
\hline H3 & Customer Experience Orientation -> Business Model Innovation & 0.189 & 2.084 & 0.037 & Significant \\
\hline H4 & digital Co-creation -> Business Model Innovation & 0.168 & 2.213 & 0.027 & Significant \\
\hline
\end{tabular}

Figure 4. shows the structural result of structural simulation model with 5000-time bootstrapping iteration

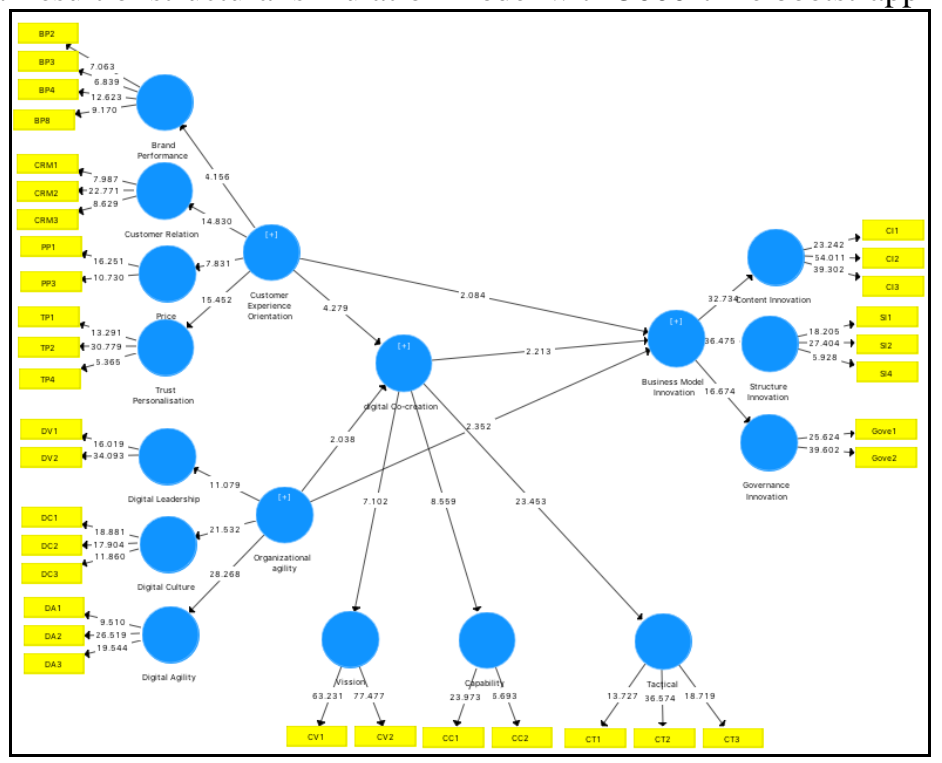

Figure 4. Structural Test Result

All indirect effects are shown in Table 4 below. It shows that digital co-creation plays significant role, as an intervening variable on the relationship between customer experience orientation and business model innovation. It also does not have an intervening effect between organizational agility and business model innovation.

Table 4. Indirect hypothesis testing Result

\begin{tabular}{|c|c|c|c|c|}
\hline Hypothesis & $\begin{array}{l}\text { Standard } \\
\text { Deviation }\end{array}$ & $\begin{array}{c}\mathbf{T} \\
\text { Statistic } \\
\mathbf{S}\end{array}$ & $\begin{array}{c}\text { P } \\
\text { Values }\end{array}$ & Remarks \\
\hline $\begin{array}{l}\text { Organizational agility }->\text { digital } \\
\text { Co-creation -> Business Model } \\
\text { Innovation }\end{array}$ & 0.085 & 1.477 & 0.140 & $\begin{array}{l}\text { not } \\
\text { Significan } \\
\mathrm{t}\end{array}$ \\
\hline $\begin{array}{l}\text { Customer Experience Orientation -> } \\
\text { digital Co-creation -> Business } \\
\text { Model Innovation }\end{array}$ & 0.108 & 2.161 & 0.031 & $\begin{array}{l}\text { Significan } \\
\mathrm{t}\end{array}$ \\
\hline
\end{tabular}




\section{V.DISCUSSION}

Findings of the current study has implications on the theory of strengthening the concept of SD-logic where the co-creation based on customer experience plays a significant role in the development of business model innovation. Customer relations and trust personalization have significant impacts in developing customer experience. Implications for practitioners are related with the model of co-creation innovation as shown in Figure 5.

The model consists of the following matrixes: (1) Co-creation innovation is the model where the customer experience orientation and organizational agility has strong influence in developing business model. Examples on this quadrant mostly come from digital companies. (2) Structural innovation is defined where the agility of organization is low, but the customer experience orientation plays a significant role in the company since it has managed the most important customers. The example of this quadrant in the matrix can mostly be found in service providers such as Internet service provider (3). There is potential innovation where firms have strong organization agility but less focus in developing customer experience. The best example of this quadrant matrix is start-ups that are more flexible but less strong on its customer base. The last (4) matrix quadrant is conventional innovation that is mostly dominated by the incumbent firm that has less organizational agility and customer experience orientation.

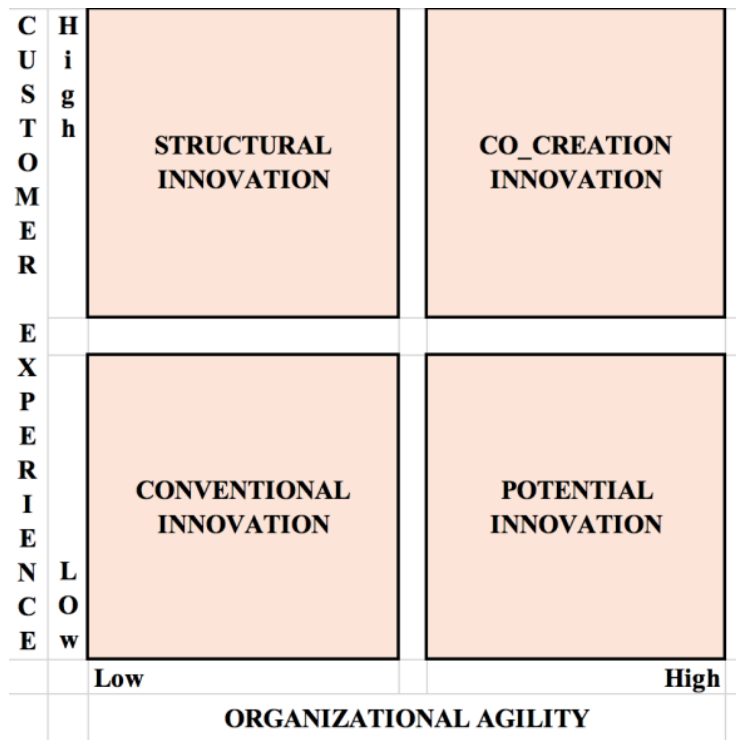

Figure 5. Co-creation-innovation model

This model provides the implication of the firms in transforming capability based on SD-logic to strengthen co-creation, thus putting attention on the implementation of co-creation to ensure the development of innovation could lead to a co-creation of values.

\section{Conclusions}

The study found that the development of SD-logic relies on co-creation-based innovation where the customer experience orientation plays a vital and positive significant role in the development of digital co-creation and business model innovation. Organization agility enables the firm to accelerate co-creation. Findings help the ICT sector to focus on existing customers and create services on top of them to transform organisations with fast and flexible decision making. The study contributes towards the initiation of a valuable model of co-creation innovation by prioritizing programs on customer experience orientation and organization agility. This has a more significant contribution in the development of business model innovation. The study has limitations in terms of sample and time of study, hence the further study can be done through expanding sampling not only in ICT but other industries across different countries. Longitudinal study can also be done to ensure the transformation in the digital era could strengthen the theoretical and practical implications.

\section{REFERENCES}

1. Arbussa, A., Bikfalvi, A., \& Marquès, P. (2017). Strategic agility-driven business model renewal: the case of an SME. Management Decision, 55(2), 271-293. https://doi.org/10.1108/MD-05-2016-0355

2. Basceanu, L. (2014). Business Model Innovation and Value Co-Creation - based on a single case study on Liz Claiborne Retrieved from http://studenttheses.cbs.dk/bitstream/handle/10417/4570/lelia_ecaterina _basceanupdf.pdf?sequence $=1$

3. Brochado, A., Troilo, M., \& Shah, A. (2017). Airbnb customer experience: Evidence of convergence across three countries. Annals of Tourism Research, 63(2017), 210-212. https://doi.org/10.1016/j.annals.2017.01.001

4. Camarinha-Matos, L. M. (2007). Collaborative Networked Organizations in Manufacturing. In IFAC Proceedings Volumes (Vol 40 , $\mathrm{pp}$

187-198)

https://doi.org/10.3182/20071002-MX-4-3906.00032

5. Chesbrough, H. (2010). Business model innovation: Opportunities and barriers. Long Range Planning, 43(2-3), 354-363. https://doi.org/10.1016/j.lrp.2009.07.010

6. Cohen, J. (1992). Quantitative Methods in psychology: A Power Primer. Psychological Bulletin, 112(1), https://doi.org/10.1016/j.jorganchem.2011.01.025

7. Crocitto, M., \& Youssef, M. (2003). The human side of organizational agility. Industrial Management and Data Systems, 103(6), 388-397. https://doi.org/10.1108/02635570310479963

8. Ercsey, I. (2017). The Role of Customers' Involvement in Value Co-creation Behaviour is Value Co-creation the Source of Competitive Advantage? Journal of Competitiveness, 9(3), 51-66. https://doi.org/10.7441/joc.2017.03.04

9. Fornell, C. and Cha, J. (1994). Partial Least Squares in Advanced Methodsof Marketing Research. Edited by R.P. Bagozzi. Cambridge, USA, Blackwell Publishers, p.52-78.

10. Frow, P., Nenonen, S., Payne, A., \& Storbacka, K. (2015). Managing Co-creation Design: A Strategic Approach to Innovation. British Journal of Management, 26(3), 463-483. https://doi.org/10.1111/1467-8551.12087

11. Gassmann, O., Frankenberger, K., \& Csik, M. (2014). Revolutionizing the Business Model - St. Gallen Business Model Navigator. Management of the Fuzzy Front End of Innovation (Vol. 18). https://doi.org/10.1007/978-3-319-01056-4_7 
12. Hair, J. F., Ringle, C. M., Sarstedt, M., \& Vinzi, E. (2014). Editorial Partial Least Squares Structural Equation Modeling: Rigorous Applications , Better Results and Higher Acceptance. Long Range Planning, 46(1-2), 1-12. https://doi.org/10.1109/MCSE.2008.47

13. Kodama, M. (2018). Service Innovation Through Collaborative Dynamic Capabilities: A Systems Approach. In M. Kodama (Ed.), Collaborative Dynamic Capabilities for Service Innovation (2018th ed., pp. 47-90). London, New York \& Shanghai: Palgrave Macmillan. https://doi.org/10.1007/978-3-319-77240-0

14. Lemon, K. N., \& Verhoef, P. C. (2016). Understanding Customer Experience Throughout the Customer Journey. Journal of Marketing, 80(6), 69-96. https://doi.org/10.1509/jm.15.0420

15. Loss, L., \& Crave, S. (2011). Agile Business Models: an Approach to support collaborative networks. Production Planning \& Control, 22(5-6), 571-580.

16. Meyer, C., \& Schwager, A. A. (2007). Understanding customer experience. Harvard Business Review. https://doi.org/10.1108/00242539410067746

17. Mihardjo, L. W. W., Alamsjah, F., Elidjen, E., \& Sasmoko, S. (2018). Digital Transformation in the Age of Industry 4 . 0: Acceleration of Transformational Performance through Business Model Innovation and Co-Creation Strategy in Indonesian ICT Firms Transformación digital en la era de la industria 4 . 0 : Aceleración del. Opcion, 86(86), 2145-2159.

18. Mihardjo, L. W. W., Sasmoko, S., Alamsjah, F., \& Elidjen, E. (2018). the Role of Distinctive Organisational Capability in Formulating Co-Creation Strategy and Business Model Innovation. Polish Journal of Management $\quad$ Studies, $\quad 18(2), \quad 197-208$. https://doi.org/10.17512/pjms.2018.18.2.16

19. Nold, H., \& Michel, L. (2013). The Performance Triangle : A Model for $\begin{array}{lll}\text { Corporate Agility. } & \text { Retrieved }\end{array}$ https://www.agilityinsights.net/media/archive1/downloads/AgilityInsigh ts-ThePerformanceTriangle.pdf

20. Osterwalder, A., \& Pigneur, Y. (2010). Business Model Generation. John Wiley \& Sons, Inc., Hoboken, New Jersey (Vol. 1). https://doi.org/10.1523/JNEUROSCI.0307-10.2010

21. Pallant, J. (2005). SPSS survival manual. Maidenhead, United Kingdom: Open University Press.

22. Palmer, A. (2010). Customer experience management: A critical review of an emerging idea. Journal of Services Marketing, 24(3), 196-208. https://doi.org/10.1108/08876041011040604

23. Ramaswamy, V. (2008). Co-creating value through customers' experiences: The Nike case. Strategy and Leadership, 36(5), 9-14 https://doi.org/10.1108/10878570810902068

24. Ramaswamy, V. (2011). It's about human experiences...and beyond, to co-creation. Industrial Marketing Management, 40(2), 195-196. https://doi.org/10.1016/j.indmarman.2010.06.030

25. Richter, S., Trier, M., \& Richter, A. (2017). Value co-creation in the digital factory - The empowered role of shop floor workers. In Australian conference on information systems (Vol. 28, pp. 1-12). Retrieved from https://www.acis2017.org/wp-content/uploads/2017/11/ACIS2017_pap er_144_FULL.pdf

26. Romero, D., \& Molina, A. (2011). Collaborative networked organisations and customer communities: Value co-creation and co-innovation in the networking era. Production Planning and Control, 22(5-6), 447-472. https://doi.org/10.1080/09537287.2010.536619

27. Roser, T., DedFillippi, R., Samson, A. (2013). Managing your co-creation mix: co-creation Ventures in distinctive Contexts. European Business Review, 25(1), 20-41. https:// doi.org/10.1108/EL-01-2017-0019

28. Seethamraju, R., \& Krishna Sundar, D. (2013). Influence of ERP systems on business process agility. IIMB Management Review, 25(3), 137-149.

https://doi.org/10.1016/j.iimb.2013.05.001

29. Seppanen, M., \& Laukkanen, I. (2015). Business model innovation: Focus on customer experience. In 2015 IEEE International Conference on Engineering, Technology and Innovation/ International Technology Management Conference, ICE/ITMC (pp. 1-9). https://doi.org/10.1109/ICE.2015.7438657

30. Sharma, S., Conduit, J., \& Hill, S. R. (2014). Organisational capabilities for customer participation in health care service innovation. Australasian $\begin{array}{lll}\text { Marketing Journal, } & \text { 22(3), } & \text { 179-188 }\end{array}$ https://doi.org/10.1016/j.ausmj.2014.08.002

31. Shrivastava, P. (2016). Effect of Co-Creation on Customer Experience, Trust and Brand Loyalty. International Journal of Sales \& Marketing Management Research and Development (IJSMMRD), 6(6), 1-14. Retrieved from http://www.tjprc.org/view-archives.php

32. Sjödin, C., \& Kristensson, P. (2012). Customers' experiences of co-creation during service innovation. International Journal of Quality and Service Sciences, 4(2), 189-204. https://doi.org/10.1108/17566691211232918

33. Teece, D., Peteratd, M., \& Leih, S. (2016). Dynamic Capabilities and Organizational Agility. California Management Review, 58(4), 4-9. https://doi.org/10.1525/cmr.2016.58.4.13

34. Trinh-Phuong, T., Molla, A., \& Peszynski, K. (2010). Enterprise systems and organisational agility: Conceptualizing the link. In ACIS 2010 Proceedings - 21st Australasian Conference on Information Systems (pp. 1-4). Retrieved from http://www.scopus.com/inward/record.url?eid=2-s2.0-84870387687\&p artnerID $=40 \& \mathrm{md} 5=\mathrm{ae} 17 \mathrm{~d} 0013 \mathrm{c} 85 \mathrm{ef} 2 \mathrm{e} 21 \mathrm{e} 7 \mathrm{~d} 4 \mathrm{~d} 50 \mathrm{~d} 257 \mathrm{dc} 6$

35. Vargo, S. L., \& Lusch, R. F. (2004). Evolving to a New Dominant Logic for Marketing. Journal of Marketing, 68(1), 1-17. https://doi.org/10.1509/jmkg.68.1.1.24036

36. Vargo, S. L., \& Lusch, R. F. (2016). Institutions and axioms: an extension and update of service-dominant logic. Journal of the Academy of Marketing Science, $\quad 44(1), \quad 5-23$ https://doi.org/10.1007/s11747-015-0456-3

37. Wirtz, B. W., Pistoia, A., Ullrich, S., \& Göttel, V. (2016). Business Models: Origin, Development and Future Research Perspectives. Long Range Planning, 49(1), 36-54 https://doi.org/10.1016/j.lrp.2015.04.001

38. Xie, K., Wu, Y., Xiao, J., \& Hu, Q. (2016). Value co-creation between firms and customers: The role of big data-based cooperative assets. Information and Management, 53(8). https://doi.org/10.1016/j.im.2016.06.003

39. Zott, C., \& Amit, R. (2017). Business Model Innovation: How to Create Value in a Digital World. Gfk Marketing Intelligence Review, 9(1), 18-23. https://doi.org/10.1515/gfkmir-2017-0003

\section{AUTHORS PROFILE}

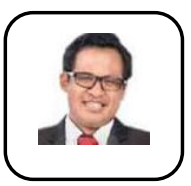

First Author Leonardus W Wasono Mihardjo is a Doctor candidate in Management at Bina Nusantara University, West Jakarta, Indonesia. His research has attracted funding award from Indonesia Ministry of research and higher education in 2019, as well as awarded as best paper in Malaysian conference 2018. 
Currently, he is a director of Financial and Business Partner at PT Telekomunikasi Indonesia International (Telin) focus on financial and development of Human capital. He is also chairman of PT Telin Australia and Board member of Telin Singapore. He has more than 20 years in Telecommunication Industry with 12 years in Telkomsel. His research interest includes digital transformation, business model innovation, technology, digital leadership and strategic management

Orcid ID ; orcid.org/0000-0002-3820-4960

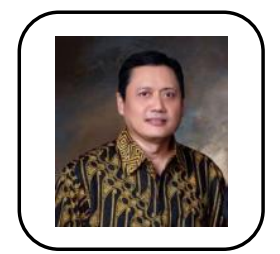

\section{Second Author Sasmoko}

Sasmoko is a Professor of Research Methods of Faculty of Humanities at Bina Nusantara University, Jakarta. He is currently working at the RIG-Education Technology, Binus University. Their most recent publication is 'Applying indonesian teacher engagement index (ITEI) apps: Self-diagnostic apps for teachers in Indonesia', including the use of Artificial Intelligent for education and social Science. His researches have attracted funding award from Indonesia Ministry of research and higher education and also from Bina Nusantara university.

His research interest includes teaching methods, teacher education and educational assessment, including the use of Technology for Education

Orcid ID: orcid.org/0000-0001-9219-9237

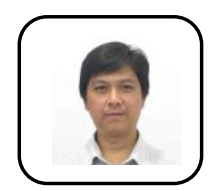

Third Author Elidjen is an Associate Professor of Computer Science at Bina Nusantara University. He obtained his Doctoral in Management from Bina Nusantara University. He has research background in computer science and more than 20 years extensive experience in Teaching and research. He has appointed as head of Binus corporation management focus on development knowledge management and innovation, including the use of artificial intelligent for social science. His research interest includes knowledge management, organization learning innovation, computer engineering and software engineering. He was graduated $\mathrm{PhD}$ in Strategic growth from Bina Nusantara University, and $M$. InfoCommTech from University of Wollongong, New South Wales, Australia.

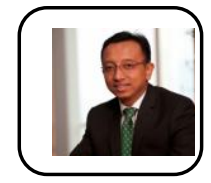

Fourth Author Dr. Riza A.N. Rukmana is currently a senior lecturer of Telkom University, a leading university in Indonesia focusing on telecommunication related studies. He is also Vice President of Marketing and Business Intelligence at PT Telkom Indonesia International (2015-current). He has more than 22 years experiences in Indonesia telecommunication industry. He joined Telkom Indonesia International since 2011 as a VP of Corporate Strategic Planning (2011-2015). Before that he was a Telkom employee since 1996 to 2011. He earned his bachelor's in industrial engineering from STT Telkom in 1995 and master's degree on Marketing Management from
Padjajaran University, Bandung, Indonesia in 1998, Dr. Riza completed his Ph.D. in Management and Economics Studies at Padjajaran University, Bandung, Indonesia in 2005. He has numerous consulting experiences in Strategy Formulation and Market Research 